\title{
Legal Issues in Quarantine and Isolation for Control of Emerging Infectious Diseases
}

\section{Cheonsoo Kim}

Sungkyunkwan University School of Law, Seoul, Korea

The Middle East respiratory syndrome coronavirus (MERS-CoV) outbreak in South Korea in 2015 has drawn public attention regarding the legal regulation of infectious disease control in Korea. This paper discusses the interpretive and legislative concerns regarding the Infectious Disease Prevention and Control Act, its ordinance and enforcement regulations, as well as public statements from the relevant administrative agency. Future improvements are also proposed.

Key words: Infectious disease, Mandatory quarantine, Compulsory hospitalization, Home quarantine, Compensation

The Middle East respiratory syndrome coronavirus (MERSCoV) outbreak in South Korea in 2015 has drawn public attention and inspired political debate regarding the regulation of infectious disease control in Korea. The discussion of the appropriateness of the regulatory system must take into account the interpretation arguments of and the legislative concerns regarding the Infectious Disease Prevention and Control Act (hereafter, 'Infectious Disease Prevention Act'), its ordinance and enforcement regulations as well as public statements from the relevant administrative agency. The Infectious Disease Prevention Act of 2015 has been much improved through two successions of amendments; through the amendments, there has been great progress in the regulation of quarantine measures in infectious disease control. The initial amendments on July 6, 2015 give the government the legal authority to im- mediately and actively order medical institutions to follow property quarantine measures when the infectious disease enters the epidemic phase. Following the amendments in December 29, 2015, financial compensation for losses incurred due to property quarantine enforcement has been established for the high effectiveness of the authority of the measures.

According to the current Infectious Disease Prevention Act, quarantine measures can be classified into five types of personal quarantine and two types of property quarantine measures. The first type of personal quarantine measure, usually called isolation, involves forcing hospitalization of 'infected patients and others' who have an infectious disease with 'high risk of transmission' as declared by the government minister in authority over the matter at an infectious disease control institution or an alternative medical facility when there is a short-
Received: January 3, 2016 Accepted: January 18, 2016

Corresponding author: Cheonsoo Kim, PhD

25-2 Sungkyunkwan-ro, Jongno-gu, Seoul 03063, Korea

Tel: +82-2-760-0619, Fax: +82-2-6243-1741

E-mail: chskim@skku.edu
This paper was based on a presentation by the author at the Korean Society of Preventive Medicine Conference, October 23, 2015. Because it addresses the specific details of the Korean Infectious Disease Control and Prevention Act, the full paper is written in Korean with this abbreviated English version for a broader readership.

This is an Open Access article distributed under the terms of the Creative Commons Attribution Non-Commercial License (http://creativecommons.org/licenses/by-nc/3.0/) which permits unrestricted non-commercial use, distribution, and reproduction in any medium, provided the original work is properly cited. 
age of facilities for infectious disease control. 'Infected patients and others' includes 'infected patients,' who have been confirmed to show symptoms of the pathogen of the infectious disease that has invaded the body, 'suspected patients,' who are suspected of having the pathogen of the infectious disease in the body but are not yet confirmed to be infected patients, and 'pathogen carriers', who show no clinical symptoms but have the pathogen of the infectious disease.

The second type of personal quarantine measure involves forcing individuals who have risks of infection or transmission, after having contact with the 'infected patients and others' as described above, to receive treatment or be isolated in their homes equipped with legally required facilities or in centers for infectious disease control. The third type of personal quarantine measure involves legislation or the minister in authority officially notifying 'infected patients and others' with infectious diseases encompassing an even narrower range than the above two types, and forcing entrance to sites acknowledged as containing such individuals, and ordering treatment and hospitalization of these individuals after their investigation and examination. In this case, the authority to enact this measure by force through mobilization of the police force against anyone who resists investigation was added by the amendment on December 29, 2015.

Meanwhile, the fourth type of personal quarantine includes forcing hospitalization or quarantine of individuals 'suspected' of being infected with pathogens of the particular infectious disease in its epidemic phase, regardless of the type of infectious disease, in an appropriate environment for a certain period of time. The last type of personal quarantine is a preventive measure, which forces hospitalization or quarantine of individuals 'suspected' of being infected with pathogens of any infectious disease, regardless of the type of infectious disease, in an appropriate environment for a certain period of time.

Out of the two types of property quarantine measures, the first type is applied to sites with 'infected patients and others' who have an infectious disease in its epidemic phase regardless of the type of infectious disease, or to sites acknowledged as being contaminated with the corresponding pathogen; it is therefore the most important measure out of all quarantine measures, including both the individual and cohort levels. The specific methods of this measure are (1) "temporary shutdown" of the site in question, (2) "forbidding entry by the general public" of the site, (3) "restriction of passage within the site in question", and (4) "other measures required for blocking pas- sage." Prior to the amendments on July 6, 2015, only measures that "block passage of the site in question for a certain period of time" were allowed and therefore, the government had no legal authority to immediately and actively take measures for the shutdown of the entire medical institution or the wards with infected patients.

Accordingly, the measures addressing shutdown of or forbidding entry to medical institutions that had been the source of MERS-CoV had been, in the past, self-administered by the medical institution; however, following the amendments, the Ministry of Health and Welfare and local government leaders gained the legal authority to actively take such measures, either all at once or selectively as necessary. If the site in question is a medical institution, method (1) involves shutdown of the entire site and method (3) involves partial shutdown. Method (2) should be applied regardless of whether complete or partial shutdown. In the case of respiratory syndromes, measures that enforce shutdown of areas within a certain distance from the medical institution in question are also allowed according to measures of (4). The second type of property quarantine measure blocks passage of the entire region or part of the region regulated by the minister in authority or by local government leaders regardless of the type of infectious disease or of its prevalence for its prevention.

Prior to the amendments in December 29, 2015, the medical institution had to deal with the loss that resulted from the first type of property quarantine measure, and this in fact acted as a barrier to the government's exercise of authority. Consequently, recent amendments have established new regulations that require the government to compensate the institutions for the loss. Nevertheless, two additional amendments to the Infectious Disease Prevention Act are required to achieve greater effectiveness of infectious disease control. First, a compensation system for the sacrifice of private interests for the public interest must be developed. The compensation fund must be consolidated as a national subsidy, and the enforcement of the corresponding measure must also be consolidated under the authority of the central government, at least for the property quarantine measures. That is, in the comparison of the value of the two rights, which are the protection of the citizen's individual rights and interests and the protection of the community, if the latter has superior ends, then it is subject to the regulation of infectious disease. The inevitable infringement on individual rights must therefore be approached in terms of national economic interests. 
Second, regulations that specify police mobilization in exercising the authority to carry out quarantine measures must be established. In order to achieve effectiveness of the quarantine measures for infectious disease control, official compensation as well as strict regulations for enforcement of the measures is required; however, currently, excluding the third type of personal quarantine measure, there are no such regulations other than ex post facto sanctions (criminal punishment in the form of a fine) under the Infectious Disease Prevention Act or ex post facto imposition of responsibility for compensation for damages under general rule of tort law. Excluding the second type of property quarantine measure, regulations through which the authorities can request police mobilization as a preliminary method of enforcing action must be established. Such methods for enactment are necessary for elevation of the effectiveness of the quarantine measures.

The steps in both personal and property quarantine measures include diagnosis of infectious disease (detection of patients and others), its notification and reporting, the corresponding quarantine measures, and official compensation for the resulting loss. The fact that infectious disease control is a government activity must not be overlooked, and private medical personnel as well as medical institutions are subsidiary institutions assisting in related affairs. Furthermore, in order to effectively control the spread of infectious disease through prompt quarantine measures, an exceptional system of direct reporting to the final decision maker must be established, as well as an exceptional system of immediate reporting and decision-making for immediate decisions on compensation in cases where a high level of compensation is expected. Meanwhile, whether the regulations associated with the detection of patients diagnosed with the infectious disease are appropriate, and especially whether the management and procedure of notification and reporting as a process of the quarantine measures is appropriate, remains in question. Detailed regulations are still needed regarding the two patient quarantine methods, which include isolation in external facilities (medical institutions, quarantine centers, etc.) and self-isolation in the patient's home.

\section{CONFLICT OF INTEREST}

The author has no conflicts of interest associated with the material presented in this paper.

\section{SUPPLEMENTAL MATERIAL}

Supplemental material (Korean version) is available at http://www.jpmph.org/.

\section{ORCID}

Cheonsoo Kim https://orcid.org/0000-0002-0588-084X 


\section{Legal Issues in Quarantine and Isolation for Control of Emerging Infectious Diseases}

\section{Cheonsoo Kim}

Sungkyunkwan University School of Law, Seoul, Korea

\section{신종감염병 관리를 위한 격리조치의 법적 측면}

김천수

성균관대학교 법학전문대학원

\section{I.서 설}

2015년 대한민국에 발생한 신종감염병은 중동호흡기증후 군(MERS)이다. 2015. 5. 20. 나타난 첫 확진자를 포함하여 186 명의 확진자가 발생하였고 이 가운데 38 명이 사망하였다. 보 건당국에 의해 같은 해 12. 23. 자정을 기해 소위 '종식'이 선언 된 2015년의 메르스 사태(이하의 '메르스 사태'는 2015년의 그 것을 의미함)는 세계보건기구가 제시한 기준(잠복기 2 배 기 간의 양성환자 전무 상태 지속)에 따라 종식되었지만, 언제 다 시 나타날 수도 있는 것이 감염병이므로 그 종식 선언으로 이 에 대한 학문적 고찰을 게을리해서는 안 된다. 이하에서는 이 번 메르스 사태와 관련된 법과 제도 가운데 격리조치의 측면 을살펴본다.

이번 메르스 사태와 관련하여 언론 등에서 관계 당국에 대 한 질타가 뜨거웠다. 따라서 이번 사태에 대한 우리 사회의 대 응이 실패로 규정될 수 있다면 우리 사회의 어느 부문에서 본 질적인 실패를 찾을 것인가? 법학자의 관점에서 볼 때 이는 의 학적 실패가 아니라 법의 실패이다. 즉 법적 제도가 미흡함에 서 실패의 근원을 찾아야 한다는 것이 메르스 사태를 회고하 는 이 법학자의 시각이다. 메르스 환자를 가장 먼저 발견하여 의학적 능력을 자랑함직도 했던 삼성서울병원의 실패는 의학 적 실패가 아니라 경영의 실패이다. 이러한 경영의 실패는 우 리 법제도가 야기한 것이라고 단언하여도 무방하다.

메르스 감염환자임을 알고도, 그래서 그 환자를 중심으로 한 격리의 필요성을 알면서도 격리 등 방역조치에 과감하게 나아가지 못한 이유는 무엇인가? 감염병으로서 격리 등 방역 조치가 필요하다고 의학적으로 판단이 내려짐에도 불구하고
그러한 조치를 지연하게 한 제도의 문제점을 살펴보고자 하 는 것이 이 글의 목적이다. 이러한 목적에서 '감염병의 예방 및 관리에 관한 법률(이는 두 차례 2015. 7. 6. 및 2015. 12. 29. 개정 되었음. 이하의 '감염병예방법, '법률', 또는 '법’은 달리 특별한 설명이 없으면 이를 가리키며, '개정법'은 2015. 12. 29. 자 개정 법률을 가리킴)'의 방역조치 가운데, 격리 및 격리의 효과가 있 는 처분 그리고 그들과 관련된 부수적 쟁점을 논의하고자 한 다. 메르스를 전후로 한 우리 법제도의 변화가 있었는데 아직 도 보완이 필요한 부분은 무엇인지도 위와 같은 관점에서 살 펴볼 것이다.

특기할 것은 이 글이 2015. 10. 23. 학회에서 발표될 당시 2015. 7. 6. 자 개정에서는 반영되지 않았던 주장 가운데 중요한 내용, 즉 의료기관 폐쇄 등으로 인한 손실을 국가재정으로 충 당하여야 한다는 주장이 그 이후 2015. 12. 29. 자, 2016. 1. 6. 자, 및 2016. 1. 7. 자로 각 개정된 감염병예방법과 그 시행령 및 시 행규칙에 반영되었다는 점이다. 발표 시에는 없었던 이들 개 정조항들을 이하에서 함께 소개한다.

\section{II. 신종감염병의 의미}

\section{1. 사회적 의미}

신종감염병이란 우선 '신종'의 감염병이다. 즉 새로운 병원 체에 의한 감염병이다. 그런데 이 신종이란 의미는 국내의 관 점이다. 국외에서 발병된 병원체에 의한 국내 발생 사실이 보 고되지 않은 감염병이지 국제적 관점에서 그러한 것이 아니 다. 신종감염병에 대한 사회적 개념의 지표는 국내 발생 또는 그 발생우려의 '신규성'이다. 


\section{Journal of}

\section{2. 법학적 의미}

1) 법률에 의한 처분의 대상인 신종감염병

신종감염병으로 분류되는 질병에 감염된 환자라면 감염병 예방법상의 방역조치의 대상이 된다. 감염병환자라고 하여도 국민으로서의 인권 등 법익에 대한 침해는 신중해야 한다. 방 역조치로 인한 공익상 이익과 그로 인한 사익의 피해 사이의 균형이라는 조건, 즉 후자를 감수할 만큼 전자의 무게가 크다 는 조건에서 방역조치가 이루어는 져야 한다. 이러한 조건이 구비되었음을 전제로 해당 환자의 권리가 제한되도록 하려면 그러한 규율은 국민의 대표인 국회의 의결을 거친 법률에 근 거가 있어야한다.

그 법률이 규율에 따라 방역조치가 이루어져야 하는 감염병 가운데 위 사회적 의미에 해당하는 것이 바로 신종감염병의 법학적 의미인 것이다. 감염병예방법에 편입되지 아니한 것 은 설사 의학적 판단이 위에서 언급한 조건이 구비된 것이라 고 하여도 감염병예방법상 처분의 대상이 아님은 물론이다.

\section{2) 감염병예방법상 신종감염병}

감염병예방법에서 신종감염병을 찾는 데는 2 단계의 선행 개념을 거쳐야한다. 즉 감염병의 개념과 제 4 군감염병이다. 법 제 2 조는 제 1 호에서 감염병을 “제 1 군감염병, 제 2 군감염병, 제 3 군감염병, 제 4 군감염병, 제 5 군감염병, 지정감염병, 세계보건 기구 감시대상 감염병, 생물테러감염병, 성매개감염병, 인수 (人獸)공통감염병 및 의료관련감염병”이라고 정의한다. 같은 조의 제 5 호에서 '제 4 군감염병'을 “국내에서 새롭게 발생하였 거나 발생할 우려가 있는 감염병 또는 국내 유입이 우려되는 해외 유행 감염병으로서 다음 각 목의 감염병"이라고 일단 제 한적 열거 방식으로 정의한다. 2015. 7. 6. 개정 이전에는 법률 제 2 조 제 5 호가 "국내에서 새롭게 발생하였거나 발생할 우려 가 있는 감염병 또는 국내 유입이 우려되는 해외 유행 감염병 으로서 보건복지부령으로 정하는 감염병을 말한다.”라고만 하고 구체적 열거는 시행규칙에 위임하였었다. 하지만 이러 한 입법태도는 감염병으로 분류됨에 따라 그 방역조치에 논 리필연적으로 수반하는 인권 등 법익 제한 내지 침해가 정당 화될 수 있다는 점에서 문제가 있었다(이 점을 지적한 2015.6. 20. 대한의료법학회에서의 발표에 관하여는 [의료법학] 제 16 권 제 2 호 204 면 이하 참조). 이러한 감염병의 구체적 열거와같 이 국민의 권리 제한에 매우 중요한 내용은 국회 의결에 의하 여 제개정이 이루어지는 법률에서 직접 규율되어야 하며 이 와 같이 개정된 현행 입법태도는 타당하다.

문제는 법률에 열거되지 아니하였지만 “국내에서 새롭게 발생하였거나 발생할 우려가 있는 감염병 또는 국내 유입이 우려되는 해외 유행 감염병"에 해당하는 경우이다. 이에 대하 여 같은 호의 단서는 "다만, 갑작스러운 국내 유입 또는 유행이 예견되어 긴급히 예방 . 관리가 필요하여 보건복지부장관이
지정하는 감염병을 포함한다."라고 하여 위 문제를 해결한다. 즉 단서는 국회의 의결절차를 거칠 여유 없는 경우를 상정한 것이다. 하지만 법률 제 2 조 제 5 호에 “파. 신종감염병증후군”이 있어서 보건복지부장관의 지정을 기다리지 않고도 위와 같은 문제의 상황에서 감염병예방법상 방역조치를 취할 수 있다. 이처럼 개정에 시간이 많이 소요되는 법률에서의 열거로 나 타나는 문제에 대하여 이중의 해결 장치를 감염병예방법은 가지고 있다. 그래서 2015년의 '메르스'라는 신종감염병은 법 령에 열거되지 않았지만 위와 같은 해법으로서 질병관리본부 가 발간하는 법정감염병 진단 . 신고 기준에 2014년에 추가되 어 대처할 수 있었고, 이제는 감염병예방법 제 2 조 제 5 호에 머. 중동 호흡기 증후군(MERS)으로 명문화되었다.

\section{III. 격리조치의 의미}

\section{1. 법률의 명문상 “격리”의 표현}

격리조치에 관한 논의를 위하여 우선 감염병예방법상 '격 리’라는 표현이 사용된 예를 조문의 순서에 따라 살펴보면 다 음과 같다. 법 제 6 조 제 1 항의 "국민은 감염병으로 격리 및 치료 등을 받은 경우 이로 인한 피해를 보상받을 수 있다.”에서 격리 는 격리된 사람이 가지는 보상청구권의 원인이다. 법 제 6 조 제 4 항의 "국민은 치료 및 격리조치 등 국가와 지방자치단체의 감염병 예방 및 관리를 위한 활동에 적극 협조하여야 한다."에 서 격리는 국민의 협조의무의 대상으로서 주된 것은 사람의 격리이겠지만 공간의 격리도 포함한다고 해석된다. 개정법 제 8 조의 2 의 "국가는 감염병환자의 진료 및 치료 등을 위하여 권역별로 보건복지부령으로 정하는 일정규모 이상의 병상 (음압병상 및 격리병상을 포함한다)을 갖춘 감염병전문병원 을 설립하거나 지정하여 운영한다."에서 격리는 전파의 차단 이 가능한 설비를 갖춘 병상 유형으로서 사람의 격리를 전제 로 한다. 개정법 제 41 조의 2 제 1 항의 "사업주는 근로자가 이 법 에 따라 입원 또는 격리되는 경우 [근로기준법] 제60조 외에 그 입원 또는 격리기간 동안 유급휴가를 줄 수 있다."에서의 격 리는 근로자의 유급휴가 사유로서의 그것으로서 사람의 격리 이다. 법 제 37 조 제 1 항 제 2 호의 "격리소 . 요양소 또는 진료소 의 설치 · 운영”에서 격리는 감염병위기 시 중앙 - 지방 정부에 의한 시설로서의 그것으로서 사람의 격리를 위한 장소에 관 한 것이다. 개정법 제 42 조 제 5 항의 "보건복지부장관, 시 · 도지 사 또는 시장 - 군수 - 구청장은 조사거부자를 자가 또는 감염 병관리시설에 격리할 수 있으며"에서의 격리란 조사거부자 에 대한 강제조치로서의 그것으로서 사람의 격리이다. 법 제 47 조 제 4 호의 "감염병병원체에 감염되었다고 의심되는 사람 을 적당한 장소에 일정한 기간 입원 또는 격리시키는 것”에서 의 격리는 동호에 따른 방역조치로서 사람의 그것이다. 법 제 49 조 제 1 항 제 14 호의 "감염병병원체에 감염되었다고 의심되 
는 자를 적당한 장소에 일정한 기간 입원 또는 격리시키는 것" 에서의 격리는 동호에 따른 예방조치로서 역시 사람의 그것 이다.

\section{2. 법률해석상 격리조치}

위에서 본 것처럼 감염병예방법상 '격리'는 거의 대부분 조 항이(제6조 제4항만이 공간의 격리를 포함한다고 해석될 뿐 임) 사람을 일정 공간에 가두어 활동의 자유를 제한하는 의미 로 사용되었다. 이는 '대인적' 조치로서 격리라고 하겠다. 하지 만 감염병예방법은 사람에 대한 조치로서의 대인적 격리 외 에도, 특정 장소 내지 공간에 대한 조치로서의 격리도 방역조 치의 내용으로 규율하고 있다. 그렇다면 감염병예방법상 격 리는 두 가지, 즉 대인적 격리조치와 대물적 격리조치로 분류 할 수 있다. 이들을 간략하게 정리한다면 다음과 같다.

대인적 조치로서의 격리란 '사람'의 격리이다. 감염병 환자 로 확진된 사람, 감염이 의심되는 사람, 감염병원체를 보유하 고 있는 사람 등을 기타의 사람들과 차단하여 감염병을 예방 및 관리 하는 조치이다. 이러한 사람을 격리하는 효과가 나타 나는 조치로서 감염병예방법은 감염병관리기관에서의 입원 치료, 자가 및 감염병관리시설에서의 치료, 조사. 진찰에 따른 강제처분으로서의 치료와 입원, 방역조치로서의 입원 - 격리, 예방조치로서의 입원 - 격리 등을 규정하고 있다. 그런데 이들 사유 대부분은 해당 의료기관 등에 대한 대물적 격리조치의 사유가 되기도 한다.

대물적 조치로서의 격리란 '공간'의 격리이다. 코호트 격리 와 같이 의료기관 등 일정한 장소를 차단하여 그 공간에 있는 사람들과 그 바깥에 있는 사람들의 접촉을 차단하여 감염병 을 예방 및 관리하는 조치이다. 그 공간에 있는 사람들을 집단 적으로 격리하는 것이다. 감염병예방법에는 2015. 7. 6. 개정되 기 이전에는 대물적 격리조치의 법적 근거가 없었지만 이 개 정 법률은 대물적 격리조치의 법적 근거를 제공하고 있다. 상 세한 것은 후술한다. 대물적 격리조치는 결과적으로 대인적 격리조치를 수반한다. 대물적 격리조치로 격리된 사람들의 집단 가운데에는 대인적 격리조치의 대상이 아닌 사람도 포 함되는 수도 있다. 따라서 대물적 격리조치는 대인적 격리조 치보다 신중하게 결정될 필요가 있다.

\section{IV. 대인적 격리조치}

위에서 언급한 바와 같이 감염병예방법에서 사람을 격리하 는 효과가 나타나는 조치로는 다음과 같은 것들이 있다.

\section{1. 입원치료에 의한 격리조치(법 제 41 조 제 1 항 및 제2항의 처분)}

제 41 조의 처분은 제 1 항 및 제 2 항의 처분과 제 3 항의 처분으
로 구분된다. 우선 전자를 살펴본다. 전자인 입원치료의 처분 은 장소에 따라 제 1 항과 제 2 항으로 나뉜다. 제 2 항은 제 1 항의 보충적 조항이다.

\section{1) 대상질병}

입원치료라는 조치에 관한 감염병예방법 제 41 조 제 1 항에 의하면 이 조치는 모든 감염병에 해당하는 것이 아니라, 보건 복지부 장관이 고시한 감염병에 한하고, 그 고시에 포함되는 감염병의 기준은 '고도의 전파위험'이다. 현재 그러한 감염병 으로는 보건복지부고시 제2013-211호 '지정감염병 등의 종류' 제7호가 정하고 있다. 이 고시는 조만간 중동호흡기증후군 (MERS)을 명시하는 개정이 이루어질 것으로 예상된다. 이 고 시는 2013. 12. 31. 시행된 것으로 그 폐지, 개정 등의 조치를 하 여야 하는 기한은 2016년 12월 31일이다.

\section{2) 대상자}

입원치료라는 조치는 위 대상질병인 "감염병에 걸린 감염 병환자등”이다. 문제는 “걸린”이라는 수식어와 “감염병환자 등”의 개념 범위에 관한 문리적 해석으로는 모순이 있다는 점 이다. “감염병환자등”이란 감염병환자, 감염병의사환자 또는 병원체보유자를 의미하며(법 제 2 조 제 17 호 참조), "감염병환 자"란 “감염병의 병원체가 인체에 침입하여 증상을 나타내는 사람으로서 제 11 조 제 5 항의 진단 기준에 따른 의사 또는 한의 사의 진단이나 보건복지부령으로 정하는 기관의 실험실 검사 를 통하여 확인된 사람"(법 제 2 조 제 13 호)이며, "감염병의사환 자”란 “감염병병원체가 인체에 침입한 것으로 의심이 되나 감 염병환자로 확인되기 전 단계에 있는 사람"(법 제2조 제 14 호) 이고, "병원체보유자”란 “임상적인 증상은 없으나 감염병병원 체를 보유하고 있는 사람”(법 제2조 제 15 호)인데, 이 가운데 “감염병에 걸린" 사람은 누구를 의미하는지 의문이다. 제 42 조 제 1 항 등 감염병예방법 전반에 걸쳐 감염병환자등이 사용된 조문의 체계적 해석에 의한다면 “걸린”이라는 문구는 의미가 없다고 여겨진다. 아무튼 이러한 모호성을 제거하는 개정이 필요하다. 나아가서 감염병의사환자인지 여부를 판단하는 주 체에 대한 규정이 없음도 이러한 모호성을 심화시키는 문제 이다. 한편 감염병환자의 진단 주체에 한의사를 획일적으로 포함시킴은 의문이다. 감염병환자등의 판단의 주체와 절차는 향후 정확한 논의를 바탕으로 하여 입법적으로 정리되어야 할 일이다.

\section{3) 장소}

위 대상자가 입원치료를 받는 장소는 모든 의료기관이 아니 라, 감염병관리기관이며(감염병관리기관의 지정, 설치, 운영 등에 관하여는 제 36 조, 제 37 조, 제 38 조, 제 64 조, 제 65 조, 제 67 조, 제 74 의2조 등 참조) 이 장소의 병상이 포화상태로 수용이 


\section{Journal of}

어려운 경우 대체의료기관(대체의료기관이라 함은 법 제 41 조 제 2 항의 의료기관을 의미하며 이하에서도 마찬가지이다)을 포함한다. 대체의료기관의 지정은 중앙정부에서는 보건복지 부 장관의 위임을 받은 질병관리본부장(법 시행령 제 32 조 제 1 항 제 15 호), 지방정부에서는 광역기초자치단체장 및 기초자 치단체장의 권한이다(법 제 41 조 제 1 항 및 제 2 항).

\section{4) 통지}

입원치료에 관한 통지의 권한은 중앙정부에서는 보건복지 부장관의 위임을 받은 질병관리본부장, 지방정부에서는 광역 자치단체장 및 기초자치단체장에게 귀속한다. 통지의 상대방 은 입원치료 대상자뿐만 아니라 그 보호자를 포함한다. 보호 자에게 피보호자인 입원치료 대상자의 소재에 대한 알 권리 가 있으므로 그에 대한 통지는 필요하다. 문제는 보호자의 범 위가 모호하다는 점이다. 상대방의 범위는 개인정보 및 사생 활 보호와 관련하여 매우 민감한 문제이다. 따라서 이를 입법 적으로 명료하고 적정하게 범위를 설정해야한다.

\section{5) 위반에 대한 제재}

법 제 41 조에 의한 입원치료를 받아야 하는 사람은 이를 거 부할 권리가 없다. 이를 거부하는 사람을 강제할 방법이 현재 로서는 없고 다만 300 만 원 이하의 벌금이라는 형사처벌(법 제 80 조 제 2 호)을 통하여 사후적으로 그리고 간접적으로 강제 할 뿐이다. 직접적 강제의 방법이 강구되어야 하며 이를 위하 여 의료기관의 장이 경찰서장 등에게 협조를 요청할 권한이 인정되는 조항이 법률에 신설될 필요가 있다. 법 시행령 별표2 제 4 호에 의하면 의료인이나 감염병관리기관 또는 의료기관 의 장은 환자를 입원시설에 입원시키고, 지체 없이 관할 보건 소장에게 신고해야 하고, 신고를 받은 관할 보건소장은 입원 치료 여부를 지체 없이 확인해야 한다고 규정할 뿐이다.

\section{6) 결정권자}

입원치료라는 조치에 관하여 이상과 같이 살펴보았지만, 감염병예방법에는 입원치료에 관한 결정권자가 누구인지에 관한 규정이 없다. 입원치료의 대상자인 감염병환자등 가운 데 감염병환자에 관한 의학적 판단의 주체로서 의사나 한의 사가 등장하지만 이들 진단 없이도 보건복지부령으로 정하는 기관의 실험실 검사로 감염병환자로 확인될 수도 있다. 나아 가서 기타 감염병의사환자나 병원체보유자에 대하여는 판단 의 주체 자체도 없다.

다만 법 시행령 제 23 조에 근거한 별표 2 에서는 제 4 호(입원 치료의 절차 등)의 가목에서 "입원치료 대상 환자 등을 진찰 또는 진단한 의료인이나 감염병관리기관 또는 의료기관의 장 은 환자를 입원시설에 입원시키고, 지체 없이 관할 보건소장 에게 신고해야 한다."는 규정이 있다. 이를 보면 대상자를 진
찰. 진단한 의료인 또는 입원치료 장소의 장이 입원을 시킬 권 한이 있는 듯이 되어 있다. 이를 입원치료의 결정권자를 규정 한 것이라고 본다면 입법 방식에 문제가 있다. 국민의 권리를 제한하는 권한인 입원치료 결정권 귀속 규정은 국회에서 제 정 및 개정이 이루어지는 법률에 있어야 한다. 이를 근거로 결 정권이 이들에게 있다는 해석은 오류이다. 위 별표의 규정은 이들에게 입원시킬 의무를 부과한 규정이다.

감염병예방법에서는 입원치료 통지권 귀속 규정이 있다. 그런데 입원치료의 통지란 그 결정의 통지이다. 결정 없는 통 지란 있을 수 없다. 여기서 통지란 그 결정 및 그 결정 내용의 전달이라고 이해한다면, 위 입원치료 통지권자(질병관리본 부장, 광역자치단체장 및 기초자치단체장)를 입원치료 결정 권자로 보는 해석이 가능하다. 물론 이들 입원치료의 결정 및 통지에 관한 권한은 의학적 판단에 관한 전문가의 의견 등 근 거를 가지고 행사하여야 할 것이다.

\section{관련규정}

법 제 41 조(감염병환자등의 관리) (1) 감염병 중 특히 전파 위험이 높은 감염병으로서 보건복지부장관이 고시한 감염병 에 걸린 감염병환자등은 감염병관리기관에서 입원치료를 받 아야한다. (2) 보건복지부장관, 시 · 도지사 또는 시장 - 군수. 구 청장은 감염병관리기관의 병상(病床)이 포화상태에 이르러 감염병환자등을 수용하기 어려운 경우에는 감염병관리기관 이 아닌 다른 의료기관에서 입원치료하게 할 수 있다. (4) 제 1 항부터 제 3 항까지의 규정에 따른 자가치료 및 입원치료의 방 법 및 절차 등에 관하여 필요한 사항은 대통령령으로 정한다.

지정감염병 등의 종류(보건복지부고시 제2013-211호)

7. [감염병의 예방 및 관리에 관한 법률] 제 41 조 제 1 항에 따 른 감염병관리기관에서 입원치료를 받아야 하는 감염병 의 종류는 다음 각 목과 같다.

가. 제 1 군 감염병 1) 콜레라 2) 장티푸스 3) 파라티푸스 4) 세 균성이질 5)장출혈성대장균감염증 6) A형간염 나. 제2군 감염병 1) 디프테리아 2) 홍역 3) 폴리오

다. 제3군 감염병 1) 결핵 2) 성홍열 3) 수막구균성수막염 4) 탄저

라. 제4군 감염병 1) 페스트 2) 바이러스성출혈열 3) 두창 4) 보툴리눔독소증 5) 중증급성호흡기증후군(SARS) 6) 조 류인플루엔자 인체감염증 7) 신종인플루엔자 8) 신종전 염병증후군

영 제 23 조(자가치료 및 입원치료의 방법 및 절차 등) 법 제 41 조 제 4 항에 따른 자가치료 및 입원치료의 방법 및 절차 등 은 별표 2 와 같다.

<별표2(자가치료 및 입원치료의 방법 및 절차 등)

3. 입원치료의 방법 
가. 호홉기를 통한 감염의 우려가 있는 감염병(이하 "호흡기 감염병"이라 한다)을 제외한 감염병의 경우 입원치료 기 간 동안 감염병관리기관이나 특별자치도지사. 시장. 군 수·구청장이 지정한 의료기관의 1 인실(세면대와 화장 실을 갖추어야 한다. 이하 같다)에 입원시켜야 한다. 다 만, 1 인실 입원이 곤란할 경우에는 같은 질환을 않는 사 람이나 재감염의 우려가 적은 환자와 공동 격리한다. 나. 호흡기 감염병의 경우 입원치료 기간 동안 감염병관리 기관이나 특별자치도지사 - 시장 - 군수 · 구청장이 지정 한 의료기관의 1 인실에 입원시키되, 그 1 인실은 문을 닫 은 상태에서 음압시설(陰壓施設)이 갖추어져 있고 공기 순환이 독립적으로 이루어져야 한다. 다만, 음압시설이 갖추어지지 않은 경우에는 단독 시설에 입원시켜야 하 고, 단독 시설 입원이 곤란할 경우에는 옆 병상의 환자에 게 호흡기를 통해 전파되지 않도록 차단 조치를 한 상태 에서 공동 격리한다.

다. 입원치료 중인 사람에 대하여 입원치료 기간 동안 병실 이탈 및 이동을 제한하도록 한다.

라. 입원치료 중인 사람의 분비물 및 배설물 등은 철저히 관 리하고, 오염된 물품은 소독을 해야한다.

마. 의료진을 포함한 입원실 출입자들을 최소한으로 제한 하고, 방문자에 대하여 1 회용 장갑 등의 개인보호구를 착용하게 하며, 손 씻기 등 감염병 전파를 차단하기 위한 적절한 조치를 하게 해야한다.

바. 환자의 진료에 사용되는 의료기구는 1 회용 기구를 사용 한 후 폐기처분하고, 1 회용으로 하는 것이 적합하지 않 은 체온계 등의 물품은 환자 전용으로 사용하도록 하여 야한다.

\section{4. 입원치료의 절차 등}

가. 입원치료 대상 환자 등을 진찰 또는 진단한 의료인이나 감염병관리기관 또는 의료기관의 장은 환자를 입원시 설에 입원시키고, 지체 없이 관할 보건소장에게 신고해 야한다.

나. 신고를 받은 관할 보건소장은 입원치료 여부를 지체 없 이 확인해야 한다.

다. 입원치료 대상자의 입원치료 기간은 감염병환자등으로 밝혀진 시점부터 증상 및 감염력이 소멸된 시점까지로 한다.

라. 입원시설의 장 및 시설에 종사하는 의료인은 치료를 통 하여 입원 해제가 가능한 사람에 대해 입원을 해제하고, 그 내용을 관할 보건소장에게 지체 없이 신고해야 하며, 관할 보건소장은 지체 없이 입원 해제 여부를 확인해야 한다.

마. 증상은 소멸되었으나 감염력이 있는 회복기 병원체보
유자의 경우에는 보건소장의 관리하에 지속적인 치료 를 받도록 하고, 감염력이 소멸될 때까지 의료기관에 입 원치료를 받거나자가치료를 하도록 해야 한다.

Ł영 제 32 조(권한의 위임 및 업무의 위탁) (1)보건복지부 장관은 법 제 76 조 제 1 항에 따라 다음 각 호의 권한을 질병관리 본부장에게 위임한다. ... 15. 법 제41조에 따른 감염병환자등 의 관리에 관한 업무

법 제 43 조(감염병환자등의 입원 통지) (1) 보건복지부장 관, 시 · 도지사 또는 시장 - 군수 · 구청장은 감염병환자등이 제 41 조에 따른 입원치료가 필요한 경우에는 그 사실을 입원치 료 대상자와 그 보호자에게 통지하여야 한다. (2) 제1항에 따른 통지의 방법 - 절차 등에 관하여 필요한 사항은 보건복지부령 으로 정한다.

Ł영 제 32 조(권한의 위임 및 업무의 위탁) (1)보건복지부 장관은 법 제 76 조제 1 항에 따라 다음 각 호의 권한을 질병관리 본부장에게 위임한다.

17. 법 제 43 조에 따른 감염병환자등의 입원 통지에 관한 업 무

ᄂ규칙 제 32 조(감염병환자등의 입원치료 통지) 법 제 43 조에 따라 질병관리본부장, 시 - 도지사 또는 시장 - 군수 · 구청 장이 입원치료가 필요하다는 사실을 입원치료 대상자와 그 보호자에게 통지할 때에는 별지 제 22 호서식의 입원치료 통지 서를 발급하여야한다.

법 제80조(벌칙) 다음 각 호의 어느 하나에 해당하는 자는 300 만 원 이하의 벌금에 처한다.

2. 제 41 조 제 1 항을 위반하여 입원치료를 받지 아니하거나같 은 조 제 2 항 및 제 3 항을 위반하여 입원 또는 치료를 거부한자

\section{2. 자가 및 감염병관리시설에서의 치료에 의한 격리조치 (법 제 41 조 제 3 항의 처분)}

위에서 본 바와 같이 제 41 조의 처분은 제 1 항 및 제 2 항의 처 분과 제 3 항의 처분으로 구분되는데, 여기서는 후자를 살펴본 다. 전자의 처분에 비하여 후자의 처분, 즉 자가 및 감염병관리 시설에서의 치료(이하에서는 '자가치료'로 약칭한다)는 보다 낮은 단계의 처분이다.

1) 대상질병

자가치료에 관한 제 3 항은 아래와 같이 대상자만 규정하고 있고 대상질병에 대한 제한을 명시하지 않고 않다. 감염병예 방법은 감염병의 예방 및 관리를 목적으로 하는 것이므로 이 


\section{Journal of}

러한 목적론적 해석상 대상질병은 당연히 감염병이어야 한 다. 문제는 입원치료의 대상질병을 제외할 것인지의 여부이 다. 제 3 항 제 1 호의 “입원치료 대상자가 아닌 사람"이 대상질병 을 기준으로 한다는 것인지 아니면 건강 상태를 기준으로 한 다는 것인지 표현이 모호하다. 이렇게 모호하게 입법하면 안 된다. 입원치료와 자가치료의 처분의 차이는 대상자 법익 침 해와 공익 보호의 차원에서 중요하기 때문이다.

문리적 및 목적론적 해석에 의한다면 법 제 41 조 제 3 항의 처 분 대상 질병은 감염병 가운데 제한이 없는 것으로 이해할 수 도 있다. 하지만 각 조항 간 체계적 해석상 법 제 41 조의 규율 대 상 질병은 제 3 항도 제 1 항이 설정한 대상질병과 동일한 것이 라고 해석되어야 할 것이다. 그렇다면 제 3 항 처분의 대상질병 도 '고도의 전파위험'이라는 기준에 따라 보건복지부 장관이 고시한 감염병에 한하고, 그 고시에 포함되는 감염병의 구체 적 내용은 위 입원치료의 대상질병에서 언급한 바와같다.

\section{2) 대상자}

자가치료의 대상자에 대한 해석도 유의할 필요가 있다. 문 리해석상 무제한인데 이는 위와 같은 목적론적 해석으로 제 한할 필요 있다. 우선 감염병관리기관이나 대체의료기관의 입원치료 대상자가 아닌 경우 자가치료 대상자가 된다(법 제 41 조 제 3 항 제 1 호). 입원치료 대상자는 자가치료의 처분을 하 여서는 안 된다는 것이 이 제 1 호의 의미이다.

입원치료 대상자 아닌 사람은 모두 자가치료 처분의 대상자 가 되는 것은 아니고, 같은 조항 제 2 호에 따라 감염병환자등과 접촉하였고 그로 인하여 감염이나 전파의 우려가 있는 사람 만이 자가치료의 대상자이다. 여기서 접촉의 종류나 범위가 모호한데 이는 감염 및 전파의 우려가 있을 정도의 그것이라 는 기준으로 해결되어야 한다. 한편 감염이나 전파의 우려가 어느 정도이어야 하는 것은 의학적 전문성의 도움을 받아 자 가치료 결정권자가 구체적으로 판단해야 할 것이다.

\section{3) 장소}

자가치료의 장소는 자가 또는 감염병관리시설이다(법 제 41 조 제 3 항, 감염병관리시설의 설치 및 운영에 관하여는 제 36 조, 제 37 조, 제 39 조, 제 64 조, 제 65 조, 제 67 조, 제 70 조, 제 74 조의 2 , 제 80조 등 참조). 자가치료 장소의 구체적 공간 규제 등에 대하여 법 시행령 제 23 조의 별표2 (자가치료 및 입원치료의 방법 및 절차 등) 제 1 호는 독립 공간이 있을 것을 원칙적으로 요구하 는 등 상세하게 규정한다. 감염병관리시설의 기준에 관하여 개정법 제 36 조 제 2 항은 보다상세한 규정을 두고 있다.

\section{4) 통지}

자가치료의 통지에 관한 규정이 없다. 물론 자가치료 결정 이 이루어지면 그 대상자에게 통지가 이루어짐은 당연하다.
그런데 입원치료의 경우처럼 자가가 아닌 감염병관리시설에 서 치료하는 경우에는 보호자에 대한 통지가 마찬가지의 이 유로 이루어져야 한다. 물론 그 보호자의 범위 등에 대한 논의 가 필요함은 입원치료의 경우와마찬가지이다.

그런데 법 시행령 제 23 조에 따른 별표에서는 제 2 호(자가치 료의 절차 등)의 '가목'은 “법 제 11 조 제 1 항에 따라 신고를 받은 관할 보건소장은 입원치료 대상이 아닌 사람과 감염병환자등 과 접촉한 사람들 중 자가치료가 필요한 사람을 결정하여 당 사자에게 알려야 하며 자가치료 여부를 확인해야 한다."라고 하여 통지권자가 보건소장인 것으로 규정한다. 하지만 입원 치료의 경우에서 보았듯이 결정권이 통지권의 전제이고, 결 정권은 아래에서 보듯이 보건소장이 아닌 것이 상위법 규정 이므로 이와 같은 통지권 귀속 규정은 상위법에 반한다.

\section{5) 위반에 대한 제재}

자가치료의 경우 치료를 거부한 자에 대한 규정 및 강제를 위한 입법론은 입원치료의 경우와 마찬가지이다.

6) 자가치료 결정권자

입원치료와 달리 자가치료의 경우에는 법률이 그 결정권자 를 명시한다. 자가치료에 관한 결정의 권한은 중앙정부에서 는 보건복지부장관의 위임을 받은 질병관리본부장, 지방정부 에서는 광역자치단체장 및 기초자치단체장에게 귀속한다.

법 시행령 제 23 조에 따른 별표에서는 제 2 호(자가치료의 절 차 등)의 '가목'은 위에서 보았듯이 “...보건소장은 입원치료 대 상이 아닌 사람과 감염병환자등과 접촉한 사람들 중 자가치 료가 필요한 사람을 결정하여 당사자에게 알려야 하며 자가 치료 여부를 확인해야 한다.”라고 하여 결정권자가 보건소장 인 것으로 규정하며 그 아래의 ‘나목'과 '다목'도 같은 전제를 취하고 있다. 이들은 상위법 제 41 조에 반하는 규정이다.

\section{관련규정}

법 제 41 조(감염병환자등의 관리) (3) 보건복지부장관, 시 도지사 또는 시장 - 군수 · 구청장은 다음 각 호의 어느 하나에 해당하는 사람에게 자가(自家) 또는 감염병관리시설에서 치 료하게 할수 있다.

1. 제 1 항 및 제 2 항에 따른 입원치료 대상자가 아닌 사람

2. 감염병환자등과 접촉하여 감염병이 감염되거나 전파될 우려가 있는 사람

(4) 제 1 항부터 제 3 항까지의 규정에 따른 자가치료 및 입원치 료의 방법 및 절차 등에 관하여 필요한 사항은 대통령령 으로 정한다.

Ł영 제 23 조(자가치료 및 입원치료의 방법 및 절차 등) 법 제 41 조 제 4 항에 따른 자가치료 및 입원치료의 방법 및 절차 등 


\section{은 별표2와 같다.}

<별표2(자가치료 및 입원치료의 방법 및 절차 등)

1. 자가치료의 방법

가. 자가치료 기간 동안 여러 사람이 함께 쓰는 공간이 아닌

곳(독립된 방)에 있어야한다.

나. 가목에 따른 자가치료가 곤란할 경우에는 같은 질환을

않는 사람이나 재감염의 우려가 적은 환자와 공동 격리

한다.

다. 진료 등을 위해 불가피하게 외출하는 경우를 제외하고, 자가치료 중인 사람은 자가 격리장소를 이탈하거나 이 동하지 않아야 한다.

라. 자가치료 중인 사람은 가능하면 다른 사람과 별도의 화

장실을 사용하고, 분비물 및 배설물 등은 철저히 관리해

야하며, 화장실 및 오염된 물품은 소독을 해야 한다.

마. 간병인을 포함한 방문자들의 출입을 최소화하고, 방문

자에 대해서는 1 회용 장갑 등의 개인보호구를 착용하게

하며, 손 씻기 등 감염병 전파를 차단하기 위한 적절한 조

치를 하게 해야 한다.

바. 자가치료 중인 사람이 사용한 1 회용 물품은 사용한 후

폐기처분하고, 1 회용으로 하는 것이 적합하지 않은 체온

계 등의 물품은 자가치료 중인 사람 전용으로 사용하도

록 하여야한다.

\section{2. 자가치료의 절차 등}

가. 법 제 11 조 제 1 항에 따라 신고를 받은 관할 보건소장은 입

원치료 대상이 아닌 사람과 감염병환자등과 접촉한 사

람들 중 자가치료가 필요한 사람을 결정하여 당사자에

게 알려야하며 자가치료 여부를 확인해야 한다.

나. 자가치료 대상자의 자가치료 기간은 감염병환자등의

경우에는 증상 및 감염력이 소멸된 시점까지로 하고, 접

촉자의 경우에는 마지막 접촉 시점부터 해당 감염병의

최대 잠복기간까지로 한다. 다만, 보건소장의 판단으로

그기간을 줄일 수 있다.

다. 관할 보건소장은 자가치료의 해제가 가능한 사람에 대

하여 자가치료를 해제해야 한다.

Ł영 제 32 조(권한의 위임 및 업무의 위탁) (1)보건복지부 장관은 법 제 76 조 제 1 항에 따라 다음 각 호의 권한을 질병관리 본부장에게 위임한다.

15. 법 제 41 조에 따른 감염병환자등의 관리에 관한 업무

법 제 36 조(감염병관리기관의 지정 등) (1) 시 ·도지사 또는 시장 - 군수 · 구청장은 보건복지부령으로 정하는 바에 따라 [의료법]에 따른 의료기관을 감염병관리기관으로 지정할 수 있다. (2) 제 1 항에 따라 지정받은 의료기관(이하 "감염병관리
기관"이라 한다)의 장은 감염병을 예방하고 감염병환자등을 진료하는 시설(이하 “감염병관리시설”이라 한다)을 설치하여 야 한다. 이 경우 보건복지부령으로 정하는 일정규모 이상의 감염병관리기관에는 감염병의 전파를 막기 위하여 전실(前 室) 및 음압시설(陰壓施設) 등을 갖춘 1 인 병실을 보건복지부령 으로 정하는 기준에 따라 설치하여야 한다. <개정 2015.12.29.> (3) 시 ·도지사또는 시장- 군수·구청장은 감염병관리시설의 설 치 및 운영에 드는 비용을 감염병관리기관에 지원하여야 한다. (4) 감염병관리기관이 아닌 의료기관이 감염병관리시설을 설 치 · 운영하려면 보건복지부령으로 정하는 바에 따라 특별자치 도지사 또는 시장 - 군수 · 구청장에게 신고하여야 한다. (5) 시 . 도지사 또는 시장 - 군수 · 구청장은 감염병 발생 등 긴급상황 발 생 시 감염병관리기관에 진료개시 등 필요한 사항을 지시할 수있다.

\section{3. 강제진입과 조사에 따른 격리조치(법 제42조의 처분)}

이 강제처분 권한의 구체적 내용은 해당 공무원으로 하여금 일정 장소에 진입하여 거기에 있는 사람들을 조사. 진찰하게 한 뒤 거기서 발견된 감염병환자등을 치료 - 입원에 의하여 격 리시키는 조치와조사거부자에 대한 강제격리의 두 가지가 있 다. 후자는 개정법 제 42 조에 의한 것인데, 이에 의하면 이 조치 의 강제처분권자는 조사거부자에 대한 조사. 진찰을 위하여 관할 경찰서장의 협조를 요청하여 격리조치를 취할 수 있고 (제 4 항 및 제 5 항), 그 결과 감염병환자등이 아닌 경우 즉시 격 리를 해제하도록 하였으며(제6항), 제5항에 따라 치료 · 입원시 킨 경우 그 보호자에게 통지하도록 했고(제7항), 제6항에 따른 즉시 해제가 이루어지지 않는 경우 인신보호법에 따른 구제를 조사거부자에게 허용한다(제 8 항).

\section{1) 대상질병}

법 제 42 조 처분은 강제 진입과 조사거부자에 대한 강력한 처 분이어서 그 대상이 되는 질병은 법 제 41 조의 처분 대상보다 더 제한적이다. 이에 대하여는 법 제 42 조 제 1 항에 열거되어 있 다. 이 가운데 신종감염병에 관하여는 제 4 호에 규정되어 있는 데, 제 4 군감염병 중 보건복지부장관이 정하는 감염병이 그것 이다. 이에 따른 보건복지부의 고시는 별도로 없고 보건복지부 담당사무관의 구두 답변에 의하면 제 41 조 제 1 항에 관한 고시, 즉 '지정감염병 등의 종류'에 관한보건복지부고시 제2013-211 호에 준하여 규율한다는 것이다. 이에 의한다면 위 고시 제7호 라목의 1) 페스트 2) 바이러스성출혈열 3) 두창 4) 보툴리눔독 소증 5) 중증급성호흡기증후군(SARS) 6) 조류인플루엔자 인체 감염증 7) 신종인플루엔자 8) 신종전염병증후군이 위 대상질 병에 해당한다. 위에서 언급한 바와 같이 이 고시는 중증급성 호흡기증후군(SARS)과 마찬가지로 중동호흡기증후군(MERS) 을 명시하는 개정이 조만간 이루어질 것으로 예상된다. 


\section{Journal of}

\section{2) 대상자}

"주거시설, 선박 · 항공기 · 열차 등 운송수단 또는 그 밖의 장 소에” 있는 모든 사람이다. 그런데 장소 역시 모든장소를 포함 한다. 결과적으로 대상자라는 요건은 위 대상질병의 감염병 환자등이다. 여기서 장소 관련 표현은 대상자를 한정하는 의 미는 없다. 다만 주거시설 등 예시된 장소에도 그러한 대상자 가 존재한다고 여겨지면 강제로 진입하는 것이 법률상 인정 되는 의미이다.

\section{3) 치료와 입원의 장소}

법 제 42 조에는 종래 치료와 입원의 장소에 관한 언급은 별 도로 없었다. 그렇다면 대상자가 위 입원치료나 자가치료의 각 요건에 따라 그 강제처분의 장소가 결정될 것이다. 그런데 개정법 제 42 조에서 조사거부자에 대하여는 강제동행 및 조사 . 진찰의 장소로 감염병관리기관을 명시하였고(제 2 항), 격리 의 장소로 자가 또는 감염병관리시설을, 위 제 2 항에 따라감염 병환자등으로 인정된 경우 치료 · 입원의 등의 장소를 감염병 관리시설로 명시하였고(제 5 항) 제 2 항과 제 5 항의 각 처분의 장 소에 관한 지정 및 기준의 규율은 대통령령에 위임하였지만 (제9항), 개정법 시행령(2016. 1. 6. 자 개정)에서는 이에 관한 규 정을 아직 두고 있지 않다. 한편 제 5 항의 장소는 감염병관리시 설인데 이를 포함하여 규율하는 제9항은 "기관"이라고 표현 하고 있어서 표현의 통일도 필요하고 기준이라는 표현은 시 설에 어울리는 것인데 이를 기관으로 하고 있으므로 이들을 정비하기 위한 개정이 필요하다. 한편 감염병관리기관의 지 정에 관한 규율을 제 36 조는 제 1 항에서 보건복지부령에 위임 하였는데 개정법 제 42 조는 그 처분의 장소인 감염병관리기관 지정에 관한 규율을 대통령령에 위임하여 이에 대한 정비를 위한 개정도 필요하다.

\section{4) 통지}

법 제 43 조의 통지 규정은 법 제 42 조를 명시하고 있지는 않 다. 하지만 법 제 42 조의 강제처분이 결국 입원치료로 이어지 는 경우 법 제 43 조의 통지 규정이 적용될 것이며, 자가치료 처 분의 경우에도 통지가 해석상 필요함을 위에서 언급하였다. 법 제 42 조 강제처분의 경우에도 이들 통지에 관한 논의를 참 조하여 통지가 있어야할 것이다. 그런데 개정법 제 42 조 제 7 항 은 조사거부자에 한하여 그 보호자에게 통지할 의무를 강제 처분권자에게 부과하고 있다. 조사 진찰에 응한 사람에 관하 여는 위에서 언급한 대로 통지의 절차를 밟아야 할 것이다.

\section{5) 위반에 대한 제재}

법 제 42 조 강제처분을 거부하는 자는 벌금 300 만 원 이하의 형사처벌에 의한 제재를 받는다. 여기서 제재의 대상자는 두 유형이다. 법 제 42 조에 따른 조사. 진찰을 거부한 사람과 그 절
차에서 발견된 '감염병환자등'이 그에 대한 치료 입원의 처분 을 거부한 사람이다.

\section{6) 결정권자}

이러한 처분의 결정권자 즉 강제처분권자는 "보건복지부장 관, 시 · 도지사 또는 시장 - 군수 - 구청장”이며 보건복지부장관 의 권한은 질병관리본부장에게 위임되어 있다. 이들의 지위 즉 권한과 책임에는 해당 공무원에 대한 해당 장소 진입 및 조 사 - 진찰 명령권 그리고 해당자에 대한 치료 · 입원 조치의 처 분이 포함되어 있었으며, 개정법 제 42 조에서는 조사거부자에 대한 권한과 책임으로서 경찰서장에 대한 협조요청권(해당 경찰서장이 정당한 사유 없으면 이에 응할 의무를 부담함), 조 사거부자에 대한 격리조치 및 해제, 그 보호자에 대한 통지 등 의 조항을 신설하였다.

\section{관련규정}

법 제 42 조(감염병에 관한 강제처분) (1) 보건복지부장관, 시 - 도지사 또는 시장 - 군수 - 구청장은 해당 공무원으로 하여 금 다음 각 호의 어느 하나에 해당하는 감염병환자등이 있다 고 인정되는 주거시설, 선박 - 항공기 - 열차 등 운송수단 또는 그 밖의 장소에 들어가 필요한 조사나 진찰을 하게 할 수 있으 며, 그 진찰 결과 감염병환자등으로 인정될 때에는 동행하여 치료받게 하거나 입원시킬 수 있다.

4. 제4군감염병 중 보건복지부장관이 정하는 감염병

(2) 보건복지부장관, 시 - 도지사 또는 시장 - 군수 - 구청장은 제 1 항에 따른 감염병환자등의 확인을 위한 조사. 진찰을 거부 하는 사람(이하 이 조에서 "조사거부자"라 한다)에 대해서는 해당 공무원으로 하여금 감염병관리기관에 동행하여 필요한 조사나 진찰을 받게 하여야 한다. <개정 2015.12.29.> (3) 제 1 항 및 제 2 항에 따라 조사. 진찰을 하거나 동행하는 공무원은 그 권한을 증명하는 증표를 지니고 이를 관계인에게 보여주 어야한다. <신설 2015.12.29.> (4) 보건복지부장관, 시·도지사 또는 시장 - 군수 - 구청장은 제 2 항에 따른 조사. 진찰을 위하여 필요한 경우에는 관할 경찰서장에게 이에 필요한 협조를 요 청할 수 있다. 이 경우 요청을 받은 관할 경찰서장은 정당한 사 유가 없으면 이에 따라야 한다. <신설 2015.12.29.> (5) 보건복 지부장관, 시 · 도지사 또는 시장 - 군수 - 구청장은 조사거부자 를 자가 또는 감염병관리시설에 격리할 수 있으며, 제 2 항에 따 른 조사 - 진찰 결과 감염병환자등으로 인정될 때에는 감염병 관리시설에서 치료받게 하거나 입원시켜야 한다. <신설 2015.12.29.> (6) 보건복지부장관, 시 · 도지사 또는 시장 - 군수 구청장은 조사거부자가 감염병환자등이 아닌 것으로 인정되 면 제 5 항에 따른 격리조치를 즉시 해제하여야 한다. <신설 2015.12.29.> (7) 보건복지부장관, 시 · 도지사 또는 시장 - 군수 . 구청장은 제 5 항에 따라 조사거부자를 치료 · 입원시킨 경우 그 
사실을 조사거부자의 보호자에게 통지하여야 한다. <신설 2015.12.29.> 8) 제6항에도 불구하고 정당한 사유 없이 격리조 치가 해제되지 아니하는 경우 조사거부자는 구제청구를 할 수 있으며, 그 절차 및 방법 등에 대해서는 [인신보호법]을 준 용한다. 이 경우 “조사거부자"는 “피수용자"로, 격리조치를 명 한 “보건복지부장관, 시 - 도지사 또는 시장 - 군수 · 구청장”은 “수용자"로 본다(다만, [인신보호법] 제6조제 1 항제 3 호는 적용 을 제외한다). <신설 2015.12.29.> (9) 제2항 및 제5항에 따라 조사 또는 진찰을 하거나 격리 등을 하는 기관의 지정 및 기준 등 필요한 사항은 대통령령으로 정한다. <신설 2015.12.29.>

Ł영 제 32 조(권한의 위임 및 업무의 위탁) (1)보건복지부 장관은 법 제 76 조제 1 항에 따라 다음 각 호의 권한을 질병관리 본부장에게 위임한다.

16. 법 제 42 조에 따른 감염병에 관한 강제처분에 관한 업무

법 제 80 조(벌칙) 다음 각 호의 어느 하나에 해당하는 자는 300 만원 이하의 벌금에 처한다.

3. 제 42 조에 따른 강제처분에 따르지 아니한 자

\section{4. 유행 단계의 대인적 격리 조치(법 제47조 제3호의 처분)}

법 제 47 조에는 대인적 격리조치와 대물적 격리조치가 모두 규정되어 있으며 대물적 격리조치는 후술한다. 앞에서 설명 한 법 제 41 조와 제 42 조는 유행 이전의 방역조치에 관한 규정 이다.

\section{1) 대상질병}

법 제 47 조의 격리조치의 대상질병은 이미 유행이 시작된 감 염병이다. 유행 이후의 방역조치이므로 감염병의 종류에 대 한 제한은 없다. 따라서 유행의 여부를 판단하는 것이 중요한 문제이다. 이에 따라 법 제 18 조에 따르면 “질병관리본부장, 시 ·도지사 또는 시장· 군수. 구청장”은 감염병 유행 우려 시 역학 조사를 지체 없이 실시하고 그 결과에 관한 정보를 의료기관 에 제공할 책임이 있다. 한편 법 시행령 제 13 조는 질병관리본 부장이 감염병의 유행 여부에 관한 조사가 긴급히 필요한 경 우 역학조사를 하도록 규정한다. 법 시행령 제 16 조는 각급 역 학조사반의 임무로 유형 사례의 수집, 분석 및 제공을 규정한 다.

\section{2) 대상자}

이미 유행이 시작된 감염병의 "병원체에 감염되었다고 의 심되는 사람”이 대상자이다. 제 41 조와 제 42 조의 처분 대상이 되는 사람이 아닌 사람이지만 이미 유행이 시작되었으므로 '의심'만으로 이러한 처분을 내리는 것이다. 해당자의 인권이 나 법익 침해의 위험이 매우 높다. 하지만 감염병에 기초한 조
치는 공익적 성격이 매우 강하다. 개인적 이익과 공공의 이익 양자 사이의 균형의 문제이다. 균형을 지나치게 고려함으로 인한 조치의 지연과 전파의 방치라는 위험을 피해야 한다. 개 인적 이익 침해의 문제는 그 손실의 충분한 보상으로 접근해 야 하며, 이에 대하여는 뒤에서 별도로 다룬다. 대상자가 "의 심”의 단계에서 감염병환자등으로 인정되더라도 법 제 41 조의 대상질병이 아니면 여전히 법 제 47 조의 처분 대상자가 된다.

\section{3) 장소와 기간}

이미 유행하는 감염병에 걸린 것으로 의심되는 사람에 대한 처분의 장소는 법 제 47 조는 “적당한 장소”라고 한다. 이러한 모 호한 표현은 위에서 언급한 “유행” 및 “의심”과 관련하여 이해 되어야 한다. 이 처분의 두 요소는 처분 대상자를 과다하게 만 드는 것이 불가피하다. 그로 인하여 대상자 모두를 감염병관 리기관의 해당 시설에 "입원 또는 격리시키는 것"은 비현실적 이다. 이 입원이나 격리의 조치 기간을 법 제 47 조는 "일정한 기 간"이라고 한다. 이렇게 기간을 모호하게 규정한 것은 위 처분 요소 "의심"과 연관되어 이해된다.

이렇게 이해가 불가능하지 않지만 “적당한 장소”와 "일정한 기간”은 보다 구체화할 필요가 있다. “의심”이라는 모호한 요 소에 의한 처분 결정 자체는 “유행”이라는 요소에 의하여 그 필요성이 인정되지만, 그 장소와 기간의 결정은 인권 및 법익 침해의 위험을 고려하여 보다 명확히 규정해야 한다.

\section{4) 통지}

법 제 47 조의 처분이 이루어진 경우 이를 가족 등에게 통지 하는 규정이 필요하다. “유행” 이후의 상황이므로 가족도 함께 그 처분의 대상이 될 수도 있지만 동거하지 아니하는 가족들 에게 그 소재 불명으로 인한 정신적 침해를 야기하여서는 안 된다. 이 처분의 결정권자가 어떠한 경우에 누구에게 통지할 것인지를 논의하여 통지 규정이 신설되어야한다.

\section{5) 위반에 대한 제재}

이 격리조치에 위반한 자는 300 만 원 이하의 벌금이라는 형 사처벌로 제재를 받는 직접적 강제의 필요성은 법 제 41 조에 의한 입원치료에서 논의된 바와 같다.

\section{6) 결정권자}

이 격리조치의 결정권자는 "보건복지부장관, 시 · 도지사 또 는 시장 · 군수 · 구청장”이며 보건복지부 장권의 이 권한과 책 임은 질병관리본부장에게 위임되어 있다.

\section{관련규정}

법 제 47 조(감염병 유행에 대한 방역 조치) 보건복지부장 관, 시 · 도지사 또는 시장 - 군수 · 구청장은 감염병이 유행하면 


\section{Journal of}

감염병 전파를 막기 위하여 다음 각 호에 해당하는 모든 조치 를 하거나 그에 필요한 일부 조치를 하여야 한다.

3. 감염병병원체에 감염되었다고 의심되는 사람을 적당한 장소에 일정한 기간 입원 또는 격리시키는 것

Ł영 제 32 조(권한의 위임 및 업무의 위탁) (1) 보건복지부 장관은 법 제 76 조 제 1 항에 따라 다음 각 호의 권한을 질병관리 본부장에게 위임한다.

17의3. 법 제 47 조에 따른 감염병 유행 시 감염병 전파를 막기 위한 조치에 관한 업무

법 제 16 조(감염병 표본감시 등) (7) 질병관리본부장은 감 염병이 발생하거나 유행할 가능성이 있어 관련 정보를 확보할 긴급한 필요가 있다고 인정하는 경우 [공공기관의 운영에 관 한 법률]에 따른 공공기관 중 대통령령으로 정하는 공공기관 의 장에게 정보 제공을 요구할 수 있다. 이 경우 정보 제공을 요 구받은 기관의 장은 정당한 사유가 없는 한 이에 따라야 한다.

법 제 18 조(역학조사) (1) 질병관리본부장, 시 · 도지사 또는 시장 - 군수 · 구청장은 감염병이 발생하여 유행할 우려가 있다 고 인정하면 지체 없이 역학조사를 하여야 하고, 그 결과에 관 한 정보를 필요한 범위에서 해당 의료기관에 제공하여야 한 다. 다만, 지역확산 방지 등을 위하여 필요한 경우 다른 의료기 관에 제공하여야 한다.

๘영 제 13 조(역학조사의 시기) 법 제 18 조 제 1 항 및 제 29 조 에 따른 역학조사는 다음 각 호의 구분에 따라 해당 사유가 발 생하면 실시한다.

1. 질병관리본부장이 역학조사를 하여야 하는 경우나, 감염 병 발생 및 유행 여부 또는 예방접종 후 이상반응에 관한 조사 가긴급히 필요한 경우

Ł영 제 16 조(역학조사반의 임무 등) (1) 역학조사반의 임 무는 다음 각 호와같다.

1. 중앙역학조사반 마. 감염병의 발생 · 유행 사례 및 예방접 종 후 이상반응의 발생 사례 수집, 분석 및 제공

2. 시 · 도 역학조사반 라. 관할 지역 감염병의 발생 - 유행 사 례 및 예방접종 후 이상반응의 발생 사례 수집, 분석 및 제공

3. 시 · 군 · 구 역학조사반 다. 관할 지역 감염병의 발생 - 유행 사례 및 예방접종 후 이상반응의 발생 사례 수집, 분석 및 제공

법 제80조(벌칙) 다음 각 호의 어느 하나에 해당하는 자는 300 만원 이하의 벌금에 처한다.

5. 제 47 조 ... 따른 조치에 위반한 자

\section{5. 예방을 위한 대인적 격리 조치(법 제49조 제1항}

\section{제14호의 처분)}

법 제 49 조는 제 1 항 제 14 호에서 예방을 위한 조치로서 대인 적 격리조치를 규정한다. 이는 유행하기 이전에 감염의 “의심" 을 기준으로 하는 조치이므로 이에 관한 권한은 매우 신중하 게 행사해야 한다. 이 제 14 호의 조치는 “유행”이라는 점을 제 외하고는 법 제 47 조의 그것과 동일하다. 구체적으로 살펴본 다.

1) 대상질병

법 제 47 조와 마찬가지로 감염병의 종류에는 제한이 없다. 즉 모든 감염병을 대상으로 한다는 점에서는 법 제 47 조와 같 지만, 중요한 차이는 유행의 단계에 있는 감염병인지의 여부 이다. 법 제 47 조의 조치는 “유행”이라는 요소가 감염병 종류의 무제한을 정당화시키지만 법 제 49 조에는 그러한 요소가 없 다. 같은 수준의 격리조치를 규정하는 법 제 41 조가 대상질병 을 엄격하게 제한하는 것과도 균형이 맞지 않는다.

2) 대상자

법 제 47 조와 동일하다. 감염병의 종류를 묻지 않고 그 감염 의 “의심”만으로 법 제 49 조에 의하여 대인적 격리 조치를 받게 하는 것은 문제이다. 유행하는 감염병도 아닌데 “의심”만으로 그러한 조치를 취하려면 "의심"스러운지 여부의 판단이 엄격 해야 한다. 즉 법 제 47 조와 달리 “의심" 여부의 판단을 보다 엄 격하게 해야 두 조문 사이 불균형을 줄일 수 있다.

그 한 방법으로 법 제 49 조 제 1 항 제 14 호의 조치에 앞서서 같 은 조항 제 3 호의 “건강진단"의 조치를 취하도록 하는 것이다. 이 건강진단 조치를 통하여 감염병 감염의 “의심”되는 사람에 한정하여 제 14 호의 대인적 격리조치를 취해야 한다. 이러한 절차를 먼저 밟도록 제 14 호에 “제 3 호의 건강진단에서”라는 문구를 삽입하는 개정이 필요하다.

3) 기타

장소와 기간, 위반에 대한 제재, 결정권자 등 규정 내용은 법 제 47 조와 동일하며 통지에 관한 규정이 없음도 동일하다. 이 들에 대한 해석 및 개정의 필요성도 법 제 47 에서 언급한 것과 마찬가지이다.

\section{관련규정}

법 제 49 조(감염병의 예방 조치) (1) 보건복지부장관, 시 . 도지사 또는 시장 - 군수. 구청장은 감염병을 예방하기 위하여 다음 각 호에 해당하는 모든 조치를 하거나 그에 필요한 일부 조치를 하여야 한다.

14. 감염병병원체에 감염되었다고 의심되는 자를 적당한 장 소에 일정한 기간 입원 또는 격리시키는 것 
Ł영 제 32 조(권한의 위임 및 업무의 위탁) (1)보건복지부 장관은 법 제 76 조제 1 항에 따라 다음 각 호의 권한을 질병관리 본부장에게 위임한다. <개정 2016.1.6.>

17의4. 법 제 49 조에 따른 감염병을 예방하기 위한 조치에 관 한 업무

법 제 80 조(벌칙) 다음 각 호의 어느 하나에 해당하는 자는 300 만원 이하의 벌금에 처한다.

5. 제 47 조 또는 제 49 조제 1 항(같은 항 제 3 호 중 건강진단에 관한 사항은 제외한다)에 따른 조치에 위반한 자

\section{V. 대물적 격리조치}

대물적 격리조치는 제 47 조와 제 49 조에서 규정한다. 전자는 유행 단계의 조치이고 후자는 예방으로서의 조치이다. 유의 할 것은 제 49 조의 각종 예방조치가 유행 이후에도 취할 수 있 다고 해석해야 한다. 물론 유행 단계에서 동일한 조치를 취할 수 있는 근거를 다른 규정에서 찾을 수 없는 경우에 한하여 그 러하다.

\section{1. 유행 단계의 대물적 격리 조치(법 제 47 조 제 1 호의 처분)}

대물적 격리조치에 관한 규정은 우선 법 제 47 조 제 1 호에서 찾을 수 있다. 이 제 1 호에서 대물적 격리조치를 적극적으로 규 율하게 된 것은 2015. 7. 6. 자 개정 이후이다. 법 제 47 조에는 대 인적 조치와 다양한 대물적 조치를 규정하고 있다. 전자인 제3 호는 이미 위에서 살펴보았고, 후자 가운데 대물적 격리의 효 과가 있는 조치인 제 1 호에 한하여 아래에서 살펴본다.

\section{1) 대상질병}

법 제 47 조 제 1 호에 의한 대물적 격리 조치의 대상질병에 대 하여는 법 제 47 조 제 3 호에 의한 대인적 격리 조치에 대하여 위 에서 논의된 것과 동일하다.

\section{2) 대상장소}

“감염병환자등이 있는 장소”와 “감염병병원체에 오염되었 다고 인정되는 장소”이다. 이 장소의 감염병환자등에 대한 대 인적 격리 조치에 관하여는 위에서 언급한 바와 같다. 전자의 장소에 대하여는 그러한 대인적 격리 조치와 여기에서 논의하 는 대물적 격리 조치가 동시에 이루어지게 된다.

\section{3) 결정권자}

위 조치의 권한은 "보건복지부장관, 시 - 도지사 또는 시장 군수. 구청장”에게 귀속된다. 이 가운데 보건복지부장관의 권 한이 종래 질병관리본부장에게 위임되지 않아 감염병신고체 계와 맞지 않는다는 점이 이 논문의 발표(2015. 10. 23. 자)에서
지적되었는데, 2016. 1. 6. 자로 법 시행령이 개정되면서 영 제 32 조(권한의 위임 및 업무의 위탁)에 제 17 호의 3 이 추가되어 이 문제가 해소되었다.

\section{4) 조치의 내용}

법 제 47 조 제 1 호의 조치는 i)위 장소의 “일시적 폐쇄”, ii)위 장소에 대한 “일반 공중의 출입금지”, iii)“해당 장소 내 이동제 한”, iv) “그 밖에 통행차단을 위하여 필요한 조치”이다. 2015.7. 6. 자 개정 이전에는 iv 의 조치와 유사하게 "장소의 교통을 일 정한 기간차단하는” 조치밖에 취할 수 없었다. 따라서 보건 당 국이 가령 의료기관의 전부나 일부 오염병동의 폐쇄를 위하 여 즉각적으로 적극적으로 취할 수 있는 법적 수단이 없었다 (이 점이 의료법학 제 16 권 제 2 호(2015. 12.31.), 197면 이하에 수 록된 논문인, 김천수, "중동호흡기증후군 2015년 사태와 관련 된 의료법령의 분석과 입법론”의 발표(2015. 6. 20. 자)에서 지 적된 바 있다).

그래서 지난 사태의 진원지인 의료기관의 폐쇄나 출입금지 는 그 이전에는 의료기관의 자율에 맡길 수밖에 없었다. 하지 만 위 개정으로 비로소 보건복지부 장관 등은 그러한 조치를 능동적으로 취할 수 있는 법적 수단을 가지게 된 것이다. 이들 조치는 전부 취할 수도 있고 필요한 것만 선택적으로 취할 수 도 있다. 위 해당장소가 의료기관인 경우 i 은 전면폐쇄이고 iii은 부분폐쇄에 해당한다. ii 의 조치는 양자에 병행되어야 할 조치이다. 호흡기증후군의 경우 iv 에 의하여 해당 의료기 관으로부터 일정 거리의 지역을 폐쇄하는 조치도 가능하다.

\section{5) 기타}

이 조치의 강제실현 수단으로는 위반자에 대한 사후적 처벌 인 벌금 300 만 원 이하의 형사처벌이라는 간접적 수단밖에 없 다. 이를 직접적으로 강제실현시킬 수 있는 규정이 필요함은 입원치료에 의한 대인적 격리 조치에서 논의한 바와 같다. 이 밖에 통지 관련 논의 등은 생략한다.

\section{관련규정}

법 제47조(감염병 유행에 대한 방역 조치) 보건복지부장 관, 시 · 도지사 또는 시장 - 군수 · 구청장은 감염병이 유행하면 감염병 전파를 막기 위하여 다음 각 호에 해당하는 모든 조치 를 하거나 그에 필요한 일부 조치를 하여야한다.

1. 감염병환자등이 있는장소나감염병병원체에 오염되었다 고 인정되는장소에 대한 다음 각 목의 조치

가. 일시적 폐쇄

나. 일반 공중의 출입금지

다. 해당장소 내 이동제한

라. 그 밖에 통행차단을 위하여 필요한 조치 


\section{Journal of}

Ł영 제 32 조(권한의 위임 및 업무의 위탁) (1)보건복지부 장관은 법 제 76 조 제 1 항에 따라 다음 각 호의 권한을 질병관리 본부장에게 위임한다. <개정 2015.1.6., 2016.1.6.>

17의3. 법 제 47 조에 따른 감염병 유행 시 감염병 전파를 막기 위한조치에 관한 업무

법 제 80 조(벌칙) 다음 각 호의 어느 하나에 해당하는 자는 300 만 원 이하의 벌금에 처한다.

5. 제 47 조 또는 제 49 조 제 1 항(같은 항 제 3 호 중 건강진단에 관한 사항은 제외한다)에 따른 조치에 위반한 자

\section{2. 예방을 위한 대물적 격리 조치(법 제49조 제1항 제 1 호의 처분)}

법 제 49 조에는 감염병의 예방을 위하여 다양한 조치를 규정 하고 있으며 그 가운데 격리의 효과가 있는 예방조치가 제 1 호 와 제 14 호의 두 가지이다. 제 14 호는 대인적 격리조치이므로 위에서 이미 언급하였다. 이하에서는 제 1 호를 살펴본다.

\section{1) 대상질병}

법 제 49 조 제 1 항 제 14 호에 의한 대물적 격리 조치의 대상질 병에 대하여는 법 제 49 조 제 1 항 제 1 호에 의한 대인적 격리 조 치에 대하여 위에서 논의된 것과 동일하다.

\section{2) 대상장소}

법 제 49 조 제 1 항 제 1 호는 그 조치의 대상장소를 "관할 지역" 이라고 하여 해당 결정권자의 행정관할을 기준으로 규정한 다. 즉 대상장소를 감염병과 연관하여 규정하지 않는다. 구체 적인 감염병환자등의 소재지나 오염 장소에 대한 조치는 위 법 제 47 조 제 1 호의 조치에 의한 것이다.

\section{3) 조치의 내용}

법 제 49 조 제 1 항 제 1 호의 조치는 “교통의 전부 또는 일부”의 차단이다. 무난한 입법이다. 이 조치는 구체적 감염병환자등 에 대한 조치도 아니고 그러한 사람이 존재하는 장소도 아니며 “감염병의 예방"을 위한 조치이므로 법 제 47 조 제 1 호와 같은 강력한 대물적 격리 조치를 위하는 것은 비합리적이다. 예방을 위하여 이러한 교통의 차단이 필요한지 여부의 판단은 의학전 문가의 전문적 의견을 바탕으로 한 결정권자의 결단이다.

\section{4) 결정권자}

법 제 49 조 제 1 항의 조치는 "보건복지부장관, 시 · 도지사 또 는 시장 - 군수 · 구청장”의 권한이다. 장관의 권한이 질병관리 본부장에게 위임된 것은 2016. 1. 6. 자로 법 시행령이 개정되면 서 영 제 32 조(권한의 위임 및 업무의 위탁)에 제 17 호의 4 가 추 가됨에 따른 것이다. 감염병 발생을 전제로 하지 않고 예방이
목적인 법 제 49 조의 권한은 감염병신고체계와는 무관하지만 위임의 체계적 통일성이라는 측면에서 적절한 개정이다.

(5) 기타

이 예방 조치로서 교통 차단에 대한 위반자는 벌금 300 만원 이하의 형사처벌에 의하여 제재된다. 유행단계의 대물적 격 리 조치의 경우와 달리 직접적으로 강제 실현시킬 수 있는 규 정이 필요한지는 의문이다. 따라서 예방단계의 조치를 실현 하는 강력한 수단이 필요하지 않다고 하겠다.

\section{관련규정}

법 제 49 조(감염병의 예방 조치) (1) 보건복지부장관, 시 도지사 또는 시장 · 군수. 구청장은 감염병을 예방하기 위하여 다음 각 호에 해당하는 모든 조치를 하거나 그에 필요한 일부 조치를 하여야한다. <개정 2015.7.6., 2015.12.29.>

1. 관할 지역에 대한 교통의 전부 또는 일부를 차단하는 것

Ł영 제 32 조(권한의 위임 및 업무의 위탁) (1)보건복지부 장관은 법 제 76 조 제 1 항에 따라 다음 각 호의 권한을 질병관리 본부장에게 위임한다. <개정 2016.1.6.>

17 의 4 . 법 제 49 조에 따른 감염병을 예방하기 위한 조치에 관 한 업무

법 제 80 조(벌칙) 다음 각 호의 어느 하나에 해당하는 자는 300 만원 이하의 벌금에 처한다.

5. 제 47 조 또는 제 49 조 제 1 항(같은 항 제 3 호 중 건강진단에 관한 사항은 제외한다)에 따른 조치에 위반한 자

\section{VI. 격리조치에 따른 손실의 보상}

\section{1. 손실의 공적 보상의 필요성}

이상에서 본 격리 조치는 공공의 이익을 위하여 개인적 인 권과 법익을 희생시킨다. 이러한 경우에 일반불법행위의 법 리로 그 손해를 논의함은 부적절하다. 나아가서 조치의 적기 를 놓치는 경우 인명의 손상은 물론 그 국가경제적 손실 즉 국 부(national wealth)의 손실이 매우 크다는 것은 2015년에 경험 한 바이다. 따라서 과잉일 정도로 강력하게 조치를 취하는 것 이 필요하다. 이러한 권한의 행사에는 경우에 따라서는 대상 자나 대상기관의 막대한 경제적 손실을 야기하기도 한다. 이 러한 손실을 감수하도록 한다면 권한의 행사가 주저될 수 밖 에 없고 이는 결국 조치의 적기를 놓치는 위험을 낳기도 한다. 이러한 점에서 방역조치의 권한에는 반드시 공적 자금에 의 한 손실 보상의 근거도 병행해야한다.

감염병예방법은 그 유례를 찾아보기 어려울 정도로 2015년 한 해에 두 차례나 개정이 이루어졌다. 즉 2015. 7. 6. 자 개정과 
2015. 12. 29. 자 개정이 그것이다. 2015.7. 6. 자 개정에서 보건복 지부장관 등의 방역조치 권한은 대폭 강화되었다. 하지만 아 쉽게도 손실 보전의 법적 근거가 충실하지 못하여 그 권한은 적기에 행사하기 어려운 모습이었고, 이 논문의 발표시(2015. 10 .23. 자)에 이러한 문제점을 지적하고 격리조치 권한의 실효 성 및 그 행사의 신속성을 위한 개정의 필요성을 강조하였다. 하지만 그 이후 2015. 12. 29. 자 개정에서 이 점도 어느 정도 감 염병예방법에 반영되어 다행이라고 생각한다. 이하에서는 격 리 조치에 따는 손실의 보전에 관한 법령의 규정을 정리한다. 유의할 것은 방역조치와 관련되어 지출된 비용의 전보는 이 하에서 다루지 않는다는 점이다.

\section{2. 대인적 격리 조치에 따른 손실 보상}

대인적 격리 조치의 대상자는 공익을 위하여 본인 질병 진 료에 필요한 정도 이상의 손실을 입게된다. 이에 대하여 법 제 6조는 보상청구권을 격리된 사람에게 인정한다. 보상청구권 자를 국민으로 한 점에서 보상의 주체는 국가로 보아야 할 것 이다.

그런데 개정법 제 70 조의 4 에 따르면 일정한 재정적 지원의 주체를 “보건복지부장관, 시 · 도지사 및 시장 - 군수 · 구청장” 으로 하고 있다. 이들은 격리 조치된 사람에게 예산의 범위에 서 치료비, 생활비 및 재정적 지원을 할 수 있다. 특히 격리된 의료인의 경우에는 보다 적극적으로 지원하다. 공익에 따른 개인의 손실에 대한 보상 체계가 매우 미온적이다. 이처럼 손 실 전보에 대하여 반사적 이익을 누리는 정도의 규정만으로 는 공익을 위한 사익의 희생을 정당화하기 곤란하다.

결국 개정법 제 70 조의 4 에 의한 지원으로 손실 전보가 미흡 한 격리 조치 대상자는 법 제6조에 따라 국가를 상대로 보상을 청구할 수 있다. 이를 위한 구체적 법령의 정비가 합리적으로 이루어질 필요가 있다.

\section{관련규정}

법 제6조(국민의 권리와 의무) (1) 국민은 감염병으로 격리 및 치료 등을 받은 경우 이로 인한 피해를 보상받을 수 있다. < 개정 2015.7.6.>

(3) 국민은 의료기관에서 이 법에 따른 감염병에 대한 진단 및 치료를 받을 권리가 있고, 국가와 지방자치단체는 이에 소 요되는 비용을 부담하여야 한다. <신설 2015.7.6.>

법 제70조의4(감염병환자등에 대한 생활지원) (1) 보건복 지부장관, 시 ·도지사 및 시장· 군수· 구청장은 이 법에 따라 입 원 또는 격리된 사람에 대하여 예산의 범위에서 치료비, 생활 지원 및 그 밖의 재정적 지원을 할수 있다.

(2) 시· 도지사 및 시장·군수 · 구청장은 제 1 항에 따른 사람 및 제 70 조의 3 제 1 항에 따른 의료인이 입원 또는 격리조치, 감염병 의 발생 감시, 예방 - 관리 및 역학조사업무에 조력 등으로 자녀
에 대한 돌봄 공백이 발생한 경우 [아이돌봄 지원법]에 따른 아 이돌봄서비스를 제공하는 등 필요한 조치를 하여야한다.

(3) 제 1 항 및 제 2 항에 따른 지원 · 제공을 위하여 필요한 사항 은 대통령령으로 정한다.

[본조신설 2015.12.29.]

\section{3. 대물적 격리 조치에 따른 손실 보상}

법 제 5 조 제 1 항은 "[의료법]에 따른 의료인 및 의료기관의 장 등은 ... 감염병 환자의 진단 및 치료 등으로 인하여 발생한 피해에 대하여 보상받을 수 있다."고 하여 감염병 관련 진료로 인한 피해에 관한 보상청구권을 인정한다. 이러한 피해는 물 론 진료비용을 의미하지는 않는다. 일단 예상되는 피해로는 의료진이 그 진료 과정에서 환자의 감염병에 감염되는 경우 를 생각할 수 있다.

문제는 이러한 청구권이 격리 조치로 인한 경우에도 적용될 수 있는지 의문이었다. 하지만 이 논문의 발표(2015. 10. 23.자) 에서는 개정법 제 70 조의 보상규정이 없었으므로 대물적 격리 조치로 인한 피해도 위 보상의 대상인 피해에 포함되는 것으 로 해석하여 보상할 것을 주장하였다. 대물적 격리 조치로 인 한 손실액이 거액으로 예상되는 사실이 그 조치 여부의 신속 한 결정에 사실상 장애가 되는 문제를 해소하기 위함이었다. 이렇게 무리한 해석에 의존할 것이 아니라 입법을 통한 해결, 즉 그러한 결정권 행사에 도움이 되는 보상 결정 구조의 합리 적 입법이 필요함을 아울러 주장하였다.

다행히 개정법 제 70 조는 대물적 격리 조치에 따른 손실의 보상에 대하여 전향적으로 개정되었다. 다만 개정법 제70조 제 1 항 제 3 호의 "의료기관의 폐쇄 또는 업무 정지 등으로 의료 기관에 발생한 손실”은 제 4 호의 “제 47 조제 1 호... 에 따른 조치 로 인하여 발생한 손실”에 포함되어 불필요하게 중복된 규정 은 앞으로 정비되어야한다.

아쉬운 것은 대물적 격리 조치 권한과 그로 인한 손실 보상 의 재원은 국가로 일원화되어야 한다는 점이 이번 개정(2015. 12. 29.자)에 반영되지 않았다는 점이다.

\section{관련규정}

법 제70조(손실보상) (1) 보건복지부장관, 시 · 도지사 및 시 장 - 군수 - 구청장은 다음 각 호의 어느 하나에 해당하는 손실 을 입은 자에게 제 70 조의 2 의 손실보상심의위원회의 심의 · 의 결에 따라 그 손실을 보상하여야 한다. <개정 2015.12.29.>

3. 이 법에 따른 의료기관의 폐쇄 또는 업무 정지 등으로 의 료기관에 발생한 손실

4. 제 47 조제 1 호, 제 4 호 및 제 5 호, 제 48 조 제 1 항, 제 49 조 제 1 항 제 4 호, 제 6 호부터 제 10 호까지, 제 12 호 및 제 13 호에 따른 조치로 인하여 발생한 손실

5. 감염병환자등이 발생 - 경유하거나 보건복지부장관, 시 . 


\section{Journal of}

도지사 또는 시장 - 군수 · 구청장이 그 사실을 공개하여 발 생한 [국민건강보험법] 제 42 조에 따른 요양기관의 손실 로서 제 1 호부터 제 4 호까지의 손실에 준하고, 제 70 조의 2 에 따른 손실보상심의위원회가 심의.의결하는 손실

(2) 제 1 항에 따른 손실보상금을 받으려는 자는 보건복지부 령으로 정하는 바에 따라 손실보상 청구서에 관련 서류 를 첨부하여 보건복지부장관, 시 · 도지사 또는 시장 - 군 수·구청장에게 청구하여야한다. <개정 2015.12.29.>

(3) 제 1 항에 따른 보상액을 산정함에 있어 손실을 입은 자가 이 법 또는 관련 법령에 따른 조치의무를 위반하여 그 손 실을 발생시켰거나 확대시킨 경우에는 보상금을 지급하 지 아니하거나 보상금을 감액하여 지급할 수 있다. <신 설 2015.12.29.>

(4) 제 1 항에 따른 보상의 대상. 범위와 보상액의 산정, 제 3 항 에 따른 지급 제외 및 감액의 기준 등에 관하여 필요한 사 항은 대통령령으로 정한다. <신설 2015.12.29.>

법 제 70 조의 2 (손실보상심의위원회) (1) 제70조에 따른 손 실보상에 관한 사항을 심의 · 의결하기 위하여 보건복지부 및 시 ·도에 손실보상심의위원회(이하 “심의위원회”라 한다)를 둔다.

(2) 위원회는 위원장 2 인을 포함한 20 인 이내의 위원으로 구 성하되, 보건복지부에 설치된 심의위원회의 위원장은 보건복지부차관과 민간위원이 공동으로 되며, 시 · 도에 설치된 심의위원회의 위원장은 부시장 또는 부지사와 민 간위원이 공동으로 된다.

(3) 심의위원회 위원은 관련 분야에 대한 학식과 경험이 풍부 한 사람과 관계 공무원 중에서 대통령령으로 정하는 바에 따라 보건복지부장관 또는 시 · 도지사가 임명하거나 위 촉한다.

(4) 심의위원회는 제 1 항에 따른 심의.의결을 위하여 필요한 경우 관계자에게 출석 또는 자료의 제출 등을 요구할 수 있다.

(5) 그 밖의 심의위원회의 구성과 운영 등에 관하여 필요한 사항은 대통령령으로 정한다.[본조신설 2015.12.29.]

Ł영 제 28 조(손실보상의 범위 및 보상액의 산정 등) (1) 법 제 70 조 제 1 항에 따라 손실을 보상하는 범위는 다음 각 호의 구분에 따른다.
1. 법 제 37 조의 경우: 의료기관이 감염병관리시설을 설치, 운영하는 데에 든 비용

2. 법 제 49 조 제 1 항제 13 호의 경우: 건물의 소유자가 해당 건 물에 대한 소독이나 그 밖에 필요한 조치를 하는 데에 든 비용

(2) 법 제 70 조 제 1 항에 따라 손실보상을 청구하려는 의료기 관의 경영자와 건물의 소유자는 보건복지부령으로 정하 는 바에 따라 손실보상청구서에 손실에 관한 증명서류를 첨부하여 보건복지부장관, 시 - 도지사 또는 시장 - 군수 . 구청장에게 제출하여야 한다.

(3) 제 2 항에 따라 청구를 받은 보건복지부장관, 시 - 도지사 또는 시장 - 군수 · 구청장은 사실조사를 하고 전문가의 자 문을 받아 보상액을 산정하여 보상금을 지급한다.

(4) 제 2 항에 따라 손실보상을 청구한 자가 제 3 항에 따라 결 정된 보상금에 대하여 불복할 때에는 그 처분을 받은 날 부터 30 일 이내에 그 처분관청에 이의를 신청할 수 있다.

ᄂ규칙 제46조(손실보상청구서) 영 제 28 조 제 2 항에 따른 손실보상청구서는 별지 제 31 호서식과 같다.

\section{VII. 결 어}

신종감염병에 대한 관리로서 격리조치를 대인적 조치와 대 물적 조치로 나누어 정리하였다. 감염병예방법상 대인적 격 리조치의 관련조항으로 법 제 41 조, 제 42 조, 제 47 조 및 제 49 조 를 분석하였다. 대물적 격리조치의 관련조항으로는 제 47 조와 제 49 조를 분석하였다. 한편 각 격리조치로 입은 손실의 보상 에 관하여 법 제 6 조, 제 70 조, 제 70 조의 2 및 제 70 조의 4 를 분석하 였다.

궁극적으로는 공익을 위한 사익의 희생에 대한 보상의 체계 가 보완되어야 한다. 그 보상의 기금은 국고로 일원화되어야 하며 그에 상응하는 조치의 권한도 중앙정부로 일원화되어야 한다. 적어도 대물적 격리조치는 그러하다.

2015. 12. 29. 자 개정은 급하게 서둔 듯하다. 세부적인 내용 에서 재개정이 필요한 모순이나 결함을 기술하였다. 앞으로 새로운 개정의 기회에 권한과 책임의 분배 내지 귀속에 관하 여 전체적으로 정비할 필요가 있다. 중앙정부의 장관 및 질병 관리본부장, 지방정부의 광역단체장 및 기초단체장에게 각 부여되는데 귀속체계의 불균형, 불완전 및 모순을 정비하고 합리적인 귀속체계를 수립할 필요가 있다. 